\title{
UPAYA MENINGKATKAN HASIL BELAJAR MATEMATIKA DENGAN STRATEGI PEMBELAJARAN ANSWER STICK PADA PESERTA DIDIK KELAS IV SD MUHAMMADIYAH MANDOMAI TAHUN PELAJARAN 2016/2017
}

\author{
OLEH : Safitriani*, Andi Setyawan**
}

\begin{abstract}
ABSTRAK
Penelitian ini bertujuan untuk mendeskripsikan aktivitas danmeningkatkan hasil belajar Matematika dengan menggunakan strategi pembelajaran answer stick. Jenis penelitian yang digunakan adalah Penelitian Tindakan Kelas (PTK). Subjek dalam penelitian ini adalah peserta didik kelas IV SD Muhammadiyah Mandomai. Teknik pengumpulan data yang digunakan adalah observasi dan tes sertaanalisis data adalahnilai rata-rata kelas dan persentase ketuntasan belajar klasikal. Hasil penelitian menunjukan bahwa penerapan strategi pembelajaran answer stick dapat meningkatkan hasil belajar Matematikadengannilaiketuntasanklasikalyaitu $94 \%$.
\end{abstract}

Kata Kunci : Hasil Belajar, Matematika, Answer Stick

\section{PENDAHULUAN}

Berdasarkan hasil observasi yang dilakukan pada hari Senin tanggal 20 Pebruari 2017 di kelas IV SD Muhammadiyah Mandomai pada pembelajaran Matematika, permasalahan yang ditemui yaitu peserta didik beberapa kali terlihat kurang memperhatikan penjelasan guru. Sebagian peserta didik belum memahami materi bilangan bulat, peserta didik sering keliru dalam menjumlahkan dan mengurangkan bilangan bulat. Selain itu, ketika guru melakukan tanya jawab kepada peserta didik mereka terlihat diam dan tidak mau menjawab pertanyaan guru. Tidak sedikit diantara peserta didik yang kurang fokus. Dalam proses pembelajaran strategi pembelajaran kurang variatif. Dengan kata lain banyak peserta didik yang menunjukan kurang antusias ketika pelajaran sedang berlangsung.
Skinner (Dimyati \& Mudjiono, 2015:19)belajar adalah suatu perilaku. Pada saat orang belajar, maka responnya menjadi lebih baik, sebaliknya bila ia tidak belajar maka responnya menurun.

Dimyati dan Mudjiono (2013:25) Hasil belajar merupakan hal yang dapat dipandang dari dua sisi yaitu sisi peserta didik dan dari sisi guru. Dari sisi peserta didik, hasil belajar merupakan tingkat perkembangan mental yang lebih baik bila dibandingkan pada saat peserta didik belajar. Sedangkan dari sisi guru, hasil belajar merupakan saat terselesainya bahan/materi pembelajaran.

Dimyati dan Mudjiono (2015:22) "Keberhasilan belajar siswa merupakan prasyarat bagi program belajar selanjutnya. Keberhasilan belajar siswa berarti "tercapainya"tujuan belajar siswa."

Dalam mencapai tujuan pendidikan perlu adanya strategi. Strategi 
digunakan untuk membantu jalan keberhasilan tercapainya tujuan yang diinginkan. Dalam dunia pendidikan, menurut J.R. David (Wina Sanjaya, 2014 : 126) strategi diartikan sebagai a plan, method, or series of activities designed to achieves a particular educational goal. Jadi, dengan demikian strategi pembelajaran dapat diartikan sebagai perencanaan yang berisi tentang rangkaian kegiatan yang didesain untuk mencapai tujuan pendidikan tertentu.

Menurut Kemp (Wina Sanjaya, 2014 : 126) strategi pembelajaran adalah suatu kegiatan pembelajaran yang harus dikerjakan guru dan siswa agar tujuan pembelajaran dapat dicapai secara efektif dan efiesien.

Permasalahan diataslah yang menyebabkan hasil belajar Matematika peserta didik bermasalah. Berdasarkan data yang didapat dari wali kelas menyatakan bahwa hasil studi mata pelajaran Matematika diketahui dari 17 peserta didik 12 peserta didik (71\%) diantaranya mendapatkan nilai $<60$ yang merupakan KKM dari mata pelajaran Matematika. Artinya hanya 5 peserta didik (29\%) yang tuntas mata pelajaran Matematika.

\footnotetext{
Berdasarkan fenomena diatas perlu adanya perbaikan dalam proses belajar mengajar. Salah satunya dengan menerapkan strategi pembelajaran yang menekankan pada hasil belajar peserta didik untuk mengembangkannya secara maksimal. Strategi pembelajaran yang dapat diterapkan oleh guru dalam pembelajaran matematika khususnya materi bilangan bulat adalah strategi
}

answer stick, karena strategi ini dapat meningkatkan hasil belajar peserta didik.

Andi B dan Alamsyah S (2015:227 ) menerangkan bahwa dalam pembelajaran stik es krim sebagai media. Bagian stik terdapat pertanyaan yang harus dijawab siswa.

StrategiPembelajaranAnswer Stick adalah permainan mengambil soal dari stik es krim secara perlahan dan hati-hati tanpa menyentuh stik es krim yang saling bertumpuk.

Penelitianinidilakukan di kelas IV

\section{SD}

MuhammadiyahMandomaiTahunPelajara n 2016/2017. Adapuntujuan yang ingindicapaidalampenelitianiniadalah:

untuk mendeskripsikan aktivitas pembelajaran Matematika menggunakan strategi pembelajaran answer stick pada kelas IV SD Muhammadiyah Mandomai tahun pelajaran 2016/2017dan untuk meningkatkan hasil belajar Matematika peserta didik kelas IV SD Muhammadiyah Mandomai tahun pelajaran 2016/2017 setelah menggunakan strategi pembelajaran answer stick.

\section{METODE PENELITIAN}

Penelitian ini merupakan Penelitian Tindakan Kelas yang merupakan terjemahan dari bahasa Inggris “Classroom Action Research",yang merupakan tindakan mengumpulkan, mengolah, menganalisis dan menyimpulkan data untuk menentukan tingkat keberhasilan jenis tindakan yang dilaksanakan oleh guru dalam proses pembelajaran. Beberapa jenis tindakan yang dimaksud yakni, strategi, 
pendekatan, model, metode, teknik dan cara-cara yang dipilih dan digunakan guru dalam melaksanakan proses pembelajaran. Penelitian tindakan kelas diawali dari adanya masalah dalam pembelajaran di kelas. Masalah tersebut kemudian dianalisis dan direfleksi untuk diketahui faktor-faktor penyebabnya. Setelah jelas faktor penyebabnya, selanjutnya masalah tersebut dirumuskan dan kemudian dicari strategi atau metode untuk memecahkan masalah tersebut.

Haryono (2015: 25) bahwa PTK adalah suatu bentuk penelitian yang bersifat reflektif dengan melakukan tindakan-tindakan tertentu agar dapat memperbaiki dan atau meningkatkan praktik-praktik pembelajaran di kelas secara lebih professional.

Penelitian tindakan kelas dilakukan dengan tindakan nyata sebagai kegiatan penelitian dalam rangka memecahkan masalah. Tindakan tersebut dilakukan pada situasi alami serta ditunjukan untuk memecahkan masalah dalam siklus kegiatan. Jenis penelitian ini melalui siklus, dimana masing-masing siklus terdiri dari 4 tahapan, yaitu perencanaan, pelaksanaan tindakan, observasi, dan refleksi.

Adapunsubjekdalampenelitianinia dalahpesertadidikkelas $\quad$ IV SD MuhammadiyahMandomai yang berjumlah 17 orang terdiri dari 8 orang laki-laki dan 9 orang perempuan. TeknikPengumpulan data yang digunakanadalahteknikobservasidantes.

Sedangkanteknikanalisis data dilakukansecarakualitatifdankuantitatif.

\section{HASIL DAN PEMBAHASAN}

Data pra tindakan terdiri atas data hasil awal (pre test). Data awal ini bertujuan untuk mengetahui tingkat kemampuan awal peserta didik terhadap materi yang dijadikan topik pembelajaran sebelum penelitian tindakan kelas berlangsung adapun bentuk tes yang dilakukan dengan memberikan soal essay sebanyak 10 butir soal pembelajaran Matematika pada materi operasi penjumlahan dan pengurangan bilangan bulat yang dilaksanakan pada hari Kamis, 13 April 2017 pukul 09.00-10.00 WIB ,. Data awal dari 17 orang peserta didik terdapat 15 peserta didik yang mendapatkan skor hasil Matematika masih rendah yakni kurang dari KKM Matematika yaitu 60 yang telah ditentukan oleh sekolah. Sedangkan 2 peserta didik lainnya mendapatkan skor $\geq$ 60. Skor tes awal selanjutnya dijadikan sebagai dasar untuk menghitung peningkatan hasil belajar individu pada siklus I.

Dari data yang dipaparkan diperoleh gambaran bahwa dengan demikian dapat disimpulkan bahwa ketuntasan belajar peserta didik pada materi "Bilangan Bulat" untuk mata pelajaran Matematika masih dibawah standar ketuntasan minimal atau belum tuntas.

Atas dasar data awal inilah, peneliti merasa perlu melakukan tindakan kelas untuk pelajaran Matematika dengan menggunakan strategi pembelajaran Answer Stick sebagai salah satu cara untuk meningkatkan hasil belajar Matematika peserta didik kelas IV SD Muhammadiyah mandomai. 
Pelaksanaan Siklus I dilakukan pada hari Selasa, 18 April 2017. Dalam pengamatan aktivitas guru, Pengamat 1 memberikan skor rata-rata 3 dan Pengamat 2 memberikan skor rata-rata 3 , sehingga diperoleh hasil rata-rata dari dua pengamat adalah 3 yang termasuk dalam kategori baik. Sedangkan dalam pengamatan aktivitas peserta didik, Pengamat 1 memberikan skor rata-rata 2,4 dan Pengamat 2 memberikan skor ratarata 2,5, sehingga diperoleh hasil ratarata dari dua pengamat adalah 2,5 yang termasuk dalam kategori cukup.Hasil penelitian pada siklus I didapat nilai ratarata 49 dan ketuntasan hasil belajar sebesar $47 \%$. Sehingga menunjukan bahwa kemampuan peserta didik tersebut belum dapat dikategorikan tuntas, yaitu hanya $47 \%$ peserta didik yang memperoleh nilai $\geq 60$. Diantara 17 orang peserta didik tersebut hanya 8 peserta didik yang memperoleh nilai 60 sampai 80. Ketuntasan belajar hanya meningkat $35 \%$ dari data awal ke siklus I yaitu $12 \%$ ke $47 \%$. Hal tersebut belum memenuhi standar minimal ketuntasan belajar yaitu $85 \%$ dengan nilai $\geq 60$.

Pelaksanaan tindakan kelas Siklus II dilakukan pada hari Kamis, tanggal 20 April 2017. Berdasarkan pengamatan kedua observer di atas, maka diperoleh hasil pengamatan terhadap aktivitas guru dengan kategori Baik. Pengamat 1 memberikan skor rata-rata 3,5 dan Pengamat 2 memberikan skor rata-rata 3,5 juga sehingga diperoleh hasil rata-rata dua pengamat adalah 3,5 yang termasuk kategori Baik. Sedangkan dalam pengamatan aktivitas peserta didik termasuk dalam kategori Baik. Pengamat 1 memberikan skor rata-rata 3,4 dan
Pengamat 2 memberikan skor rata-rata 3,4 . Sehingga diperoleh hasil rata-rata dari dua pengamat adalah 3,4 yang termasuk dalam kategori Baik.Berdasarkan hasil data pengamatan terhadap aktivitas guru dan peserta didik diketahui bahwa hasil yang didapatkan pada siklus II lebih baik dari siklus I. Hal ini menunjukan bahwa peneliti sudah berhasil meningkatkan aktivitas guru dan peserta didik.

Berdasarkan perhitungan nilai rata-rata dan ketuntasan klasikal hasil belajar, didapat hasil tes siklus II terlihat dari nilai hasil belajar Matematika pada materi bilangan bulat SD Muhammadiyah Mandomai didapat nilai rata-rata sebesar 65 dan ketuntasan hasil belajar sebesar 94 $\%$. Hal ini menunjukan bahwa kemampuan peserta didik tersebut dapat dikategorikan tuntas.

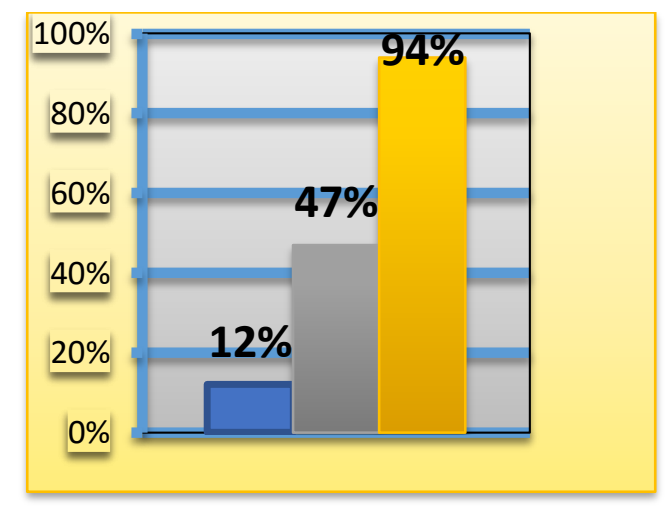

\section{Diagram Persentase Ketuntasan Belajar Klasikal \\ Kelas IV SD Muhammadiyah Mandomai}

Berdasarkan tabel dan diagram di atas, hasil data awal siklus I dan siklus II terlihat adanya peningkatan hasil belajar pada pelajaran Matematika pada materi bilangan bulat dengan menggunakan strategi pembelajaran answer stick pada peserta kelas IV SD 
Muhammadiyah Mandomai. Dapat diliht bahwa pada data awal peserta didik hanya memperoleh nilai rata-rata 26 nilai ini masih jauh dari Kriteria Ketuntasan Minimum yaitu60. Hasil ketuntasan belajar peserta didik pun hanya memperoleh nilai sebesar $12 \%$. Nilai ini sangat jauh dari kriteria ketuntasan klasikal. Dimana nilai yang ditentukan yaitu $85 \%$.

Kemudian pada siklus I nilai rata-rata peserta didik meningkat menjadi 49 nilai ini pun masih jauh dari kriteria ketuntasan minimum. Hasil ketuntasan klasikal belajar peserta didik pun meningkat yakni memperoleh nilai $47 \%$ tetapi masih belum memenuhi target indikator keberhasilan sehingga dilanjutkan lagi dalam siklus II yang mana pada siklus II memperoleh nilai rata-rata 65. Nilai ini mengalami peningkatan dan mencapai ketuntasan minimum. Nilai ketuntasan belajar klasikal pun mengalami peningkatan menjadi $94 \%$. Berdasarkan hasil tersebut telah terjadi peningkatan hasil belajar Matematika dengan menggunakan strategi pembelajaran answer stick.

\section{KESIMPULAN}

Berdasarkan data hasil penelitian yang dibahas, maka dapat disimpulkan :

1. Aktivitas belajar peserta didik kelas IV SD Muhammadiyah Mandomai pada pelajaran Matematika dengan menggunakan strtategi pembelajaran answer stick menjadi baik. Hal tersebut terlihat dari keaktifan dan semangat peserta didik mengikuti pembelajaran Matematika, dibuktikan dengan hasil observasi pada siklus I adalah 2,5 dengan kategori cukup dan siklus II meningkat menjadi 3,4 dengan kategori baik.

2. Ada peningkatan hasil belajar Matematika dengan menggunakan strategi pembelajaran answer stick pada peserta didik kelas IV SD Muhammadiyah Mandomai. Peningkatan tersebut dapat dilihat dari hasil belajar peserta didik pada mata pelajaran Matematika khususnya pada materi bilangan bulat. Pada siklus I perolehan nilai rata-rata peserta didik 49 dengan ketuntasan klasikal $47 \%$ dan mengalami peningkatan pada siklus II dengan rata-rata nilai 65 dan ketuntasan klasikal $94 \%$.

\section{DAFTAR PUSTAKA}

Dimyati \&Mudjiono. (2015). Belajar \& Pembelajaran. Jakarta: Rineka Cipta Haryono. (2015). Bimbingan Teknik Menulis Penelitian Tindakan Kelas (PTK). Purwerejo: Amara $\mathrm{F}$

Sanjaya, Wina. (2014). Strategi Pembelajaran Berorientasi Standar Proses Pendidikan. Jakarta: Kencana Prenadamedia Group. 